\title{
Respiration in mixes of sandy and clay soils: influence of clay type and addition rate
}

\author{
T.-T. Nguyen ${ }^{1 *}$, P. Marschner ${ }^{1}$ \\ ${ }^{I}$ School of Agriculture, Food and Wine, The Waite Research Institute, The University of Adelaide, Adelaide, \\ South Australia 5005, Australia.
}

"Corresponding author: trung.nguyen@adelaide.edu.au.

\begin{abstract}
In an incubation experiment, a sandy top soil was mixed with kaolinite- or smectite-rich clay soil at 15, 22.5 and $30 \%$ clay addition rates. Compared to sandy soil alone, smectite clay soil addition at 22.5 and $30 \%$ reduced cumulative respiration per $\mathrm{g}$ organic $\mathrm{C}$ whereas kaolinite clay soil addition had no effect. This can be explained by the higher surface area and cation exchange capacity of the smectite compared to kaolinite clay soil which protects native organic $\mathrm{C}$ from decomposition by binding.
\end{abstract}

Keywords: Kaolinite, organic $\mathrm{C}$ sequestration, respiration, smectite.

\section{Introduction}

Sandy soils have low water and nutrient retention capacity compared to finer textured soils. Addition of clay soils to sandy soil has been shown to increase water and nutrient retention and thereby plant growth (Hall et al., 2010). It could also increase organic $\mathrm{C}$ retention because binding to clay particles and occlusion within aggregates reduces organic $\mathrm{C}$ accessibility to decomposers (Baldock, 2007). It has been shown recently that clay addition to sandy soil reduces cumulative respiration when organic C is added (Roychand and Marschner, 2013;
Shi and Marschner, 2012). However, in those studies, only one type of clay soil was added and at one rate. Clay minerals differ in a range of properties that can influence their capacity to bind organic $\mathrm{C}$, such as surface area (Kaiser et al., 1996), cation exchange capacity (Amato and Ladd, 1992) and concentration of Fe oxides (Kaiser et al., 1996). For example compared to kaolinite, smectite has a greater surface area and cation exchange capacity (Amezketa, 1999). Consequently, clay soils with kaolinite as dominant clay mineral often have a lower 
organic C content than smectite-rich clay soils. This aim of this study was to investigate how clay type and addition rate influence soil respiration in sandy soil. We hypothesised that (i) compared to sandy soil alone, respiration will be more strongly reduced by addition of the smectite-rich than by the kaolinite-rich clay soil, (ii) the reduction in respiration by clay will increase with clay addition rate.

\section{Materials and Methods}

Sandy soil (0-15 cm) and kaolinite-rich subsoil (> $40 \mathrm{~cm}$ depth, 49\% clay) were collected from the Eyre Peninsula, South Australia (55'45'S, $\left.135^{\circ} 51^{\prime} \mathrm{E}\right)$. In this area, addition of clay-rich subsoil to sandy soils is wide-spread among landholders. The smectite-rich subsoil (68.5\% clay) was collected $(>40 \mathrm{~cm})$ from Woolumbool, South Australia (36 $\left.48^{\circ} \mathrm{S}, 140^{\circ} 08 \mathrm{E}\right)$ (Table 1). All soils were air-dried and sieved to $<2 \mathrm{~mm}$.

There were seven soil treatments: sandy soil alone or sandy soil mixed with kaolinite- or smectite-rich clay soil at 15, 22.5 and $30 \%$ of clay addition rate which is equivalent to 30.6 , 45.9 and $61.2 \mathrm{~g}$ of kaolinite-rich or 21.9, 32.9 and $43.8 \mathrm{~g}$ of smectite-rich clay soil per $100 \mathrm{~g}$ of the mixes. The sandy soil alone and the mixes with $15 \%$ clay were adjusted to $75 \%$ and the mixes with 22.5 and $30 \%$ clay were adjusted to $45 \%$ of maximum water holding capacity (WHC) with deionised water. These water contents were chosen because Setia et al. (2011) showed that they maximise soil respiration in soils with these clay contents. Then, the moist soils were preincubated for 14 days at $22^{\circ} \mathrm{C}$ to reactivate the soil microbes. The pre-incubated soil (30 g dry weight) was filled into polyvinyl cores (PVC,
$3.7 \mathrm{~cm}$ width and $5.0 \mathrm{~cm}$ height) with a nylon mesh base $(0.75 \mu \mathrm{m}$, Australian Filter Specialist Pty Ltd, Huntingwood NSW, Australia) and packed to a bulk density of $1.3 \mathrm{~g} \mathrm{~cm}^{-3}$. The cores were placed into $1 \mathrm{~L}$ glass jars after which the jars were sealed with gas tight lids equipped with septa to allow quantification of the $\mathrm{CO}_{2}$ concentration in the headspace (Setia et al., 2011). Soil respiration was also measured in the unamended clay soils alone (3 replicates). The water content was adjusted to $45 \%$ and $20 \%$ of WHC for kaolinite- and smectite-rich clay soils, respectively. The jars were incubated in the dark at 21 to $24^{\circ} \mathrm{C}$ for 22 days during which the $\mathrm{CO}_{2}$ concentration was measured every 1 - 2 days. The water content was maintained by weight. To account for differences in organic $\mathrm{C}$ content of the soils and mixes and as indicator of organic $\mathrm{C}$ accessibility to decomposers, cumulative $\mathrm{CO}_{2}-\mathrm{C}$ (respiration) is expressed per $\mathrm{kg}$ organic $\mathrm{C}$.

The contribution of the sandy and clay soils to cumulative respiration in the mixes was calculated by multiplying the weight of each soil (sandy or clay soil) by cumulative respiration of the soils alone.

Specific surface area was determined by the water vapour sorption method (Newman, 1983) using $\mathrm{LiNO}_{3}, \mathrm{KC}_{2} \mathrm{H}_{3} \mathrm{O}_{2}$ and $\mathrm{LiCl}$ to obtain different water vapour pressures. Total organic carbon was determined by wet oxidation and titration (Walkley and Black, 1934). The mineralogy of the $<2 \mu \mathrm{m}$ clay fraction was measured by X-ray diffraction (Brindley, 1980). Sodium absorption ratio (SAR) was calculated from the concentration of water extractable cations $\left(\mathrm{Na}^{+}, \mathrm{K}^{+}, \mathrm{Ca}^{2+}\right.$ and $\left.\mathrm{Mg}^{2+}\right)$ which was measured in a 1:5 soil: water suspension after $1 \mathrm{~h}$ end-over-end shaking (Table 1). Cation 
exchange capacity was calculated from the concentration of exchangeable cations $\left(\mathrm{Na}^{+}\right.$, $\mathrm{K}^{+}, \mathrm{Ca}^{2+}$ and $\mathrm{Mg}^{2+}$ ) which were determined after removal of the soluble salts by washing $5 \mathrm{~g}$ soil with $25 \mathrm{ml}$ of ethanol $(60 \%)$ as described in Rayment and Lyons (2011). The concentrations of extractable and exchangeable $\mathrm{Na}^{+}, \mathrm{K}^{+}, \mathrm{Ca}^{2+}$ and $\mathrm{Mg}^{2+}$ in the soil extracts were measured by inductively coupled plasma-atomic emission spectroscopy (ICP-AES).

Data of soil properties and cumulative respiration was analysed by one-way ANOVA. Tukey test was used to assess which soil treatments differed significantly from each other $(P \leq 0.05)$.

\section{Results}

The clay content was lower in kaolinite clay soil than in smectite clay soil (49\% and 68.5\%) (Table 1 ). The concentration of the Fe oxides (goethite and hematite) estimated by XRD was $2 \mathrm{wt} \%$ in the kaolinite clay soil and below detection limit for the smectite clay soil (data not shown). The $\mathrm{pH}, \mathrm{EC}, \mathrm{WHC}$ and total organic C increased in the following order: sandy soil $<$ kaolinite $<$ smectite clay soil (Table 1). Cation exchange capacity and surface area were two-fold higher in smecite than in kaolinite clay soil. However, cumulative respiration per $\mathrm{g}$ soil organic carbon (mg- $\mathrm{CO}_{2} \mathrm{~g} \mathrm{C}^{-1}$ ) was five-times lower in smectite than in kaolinite clay soil and sandy soil (Table 1).

Table 1. Selected properties of soils. Within rows, different letters indicate significant differences $(P \leq 0.05)(n=3$, except for particle size where $n=1)$.

\begin{tabular}{|c|c|c|c|c|c|}
\hline \multicolumn{2}{|c|}{ Properties } & \multirow{2}{*}{$\begin{array}{c}\text { Unit } \\
\%\end{array}$} & \multirow{2}{*}{$\begin{array}{c}\text { Sandy soil } \\
0.2\end{array}$} & \multirow{2}{*}{$\begin{array}{c}\begin{array}{c}\text { Kaolinite } \\
\text { clay soil }\end{array} \\
49.0\end{array}$} & \multirow{2}{*}{$\begin{array}{c}\begin{array}{c}\text { Smectite } \\
\text { clay soil }\end{array} \\
68.5\end{array}$} \\
\hline Particle size & Clay & & & & \\
\hline & Silt & $\%$ & 5.8 & 12.5 & 12.4 \\
\hline & Sand & $\%$ & 94 & 38.5 & 19.1 \\
\hline \multicolumn{3}{|l|}{$\mathrm{pH}_{1: 5}$} & $8.3^{\mathrm{b}}$ & $5.5^{\mathrm{a}}$ & $9.1^{\mathrm{c}}$ \\
\hline \multicolumn{2}{|c|}{ Electrical conductivity $1: 5$} & $\mu \mathrm{S} \mathrm{cm}^{-1}$ & $18^{\mathrm{a}}$ & $71^{\mathrm{b}}$ & $934^{\mathrm{c}}$ \\
\hline \multicolumn{2}{|c|}{ Water holding capacity } & $\mathrm{g} \mathrm{kg}^{-1}$ & $86.6^{\mathrm{a}}$ & $218.5^{\mathrm{b}}$ & $837.4^{\mathrm{c}}$ \\
\hline \multicolumn{2}{|l|}{ Surface area } & $\mathrm{m}^{2} \mathrm{~g}^{-1}$ & nd & $286^{\mathrm{a}}$ & $502^{\mathrm{b}}$ \\
\hline \multicolumn{2}{|c|}{ Total organic C } & $\mathrm{g} \mathrm{kg}^{-1}$ & $1.2^{\mathrm{a}}$ & $4.2^{\mathrm{b}}$ & $11.2^{\mathrm{c}}$ \\
\hline \multicolumn{2}{|c|}{ Cation exchange capacity } & $\mathrm{cmol}_{\mathrm{c}} \mathrm{kg}^{-1}$ & nd & $11.2^{\mathrm{a}}$ & $25.2^{\mathrm{b}}$ \\
\hline \multicolumn{2}{|c|}{ Sodium absorption ratio } & & nd & $0.8^{\mathrm{a}}$ & $6.1^{\mathrm{b}}$ \\
\hline \multicolumn{2}{|c|}{ Cumulative respiration $^{1}$} & $\mathrm{mg}-\mathrm{CO}_{2} \mathrm{~g} \mathrm{C}^{-1}$ & $109^{\mathrm{b}}$ & $105^{\mathrm{b}}$ & $23^{\mathrm{a}}$ \\
\hline
\end{tabular}

${ }^{1}$ Cumulative respiration after 22 days. nd is not determined. 
At a given clay addition rate in the mixes, smectite clay soil contributed more to the total organic $\mathrm{C}$ than the kaolinite clay soil (Figure 1). For the mixes with kaolinite clay soil, this was only the case at 22.5 and $30 \%$ clay addition rate. Compared to the contribution of the clay soils, sandy soil only contributed more in the mix with $15 \%$ clay from kaolinite clay soil whereas the contribution of the smectite clay soil was always greater than of the sandy soil.

Addition of kaolinite clay soil did not reduce cumulative respiration compared to sandy soil alone at any clay addition rate, but addition of smectite clay soil reduced cumulative respiration compared to sandy soil alone at 22.5 and $30 \%$ clay addition rates (Figure 2).
The calculated contribution to cumulative respiration in the treatments was greater for kaolinite than the smectite clay soil (Table 2). Compared to the contribution of the sandy soil, kaolinite clay soil contributed more to cumulative respiration at the two higher clay addition rates whereas the contribution of smectite clay soil was always lower. At similar clay addition rate, smectite-rich clay soil had a greater surface area and CEC than kaoliniterich clay soil (data not shown). Smectiterich clay soil had a greater $\mathrm{pH}$ and electrical conductivity than kaolinite-rich clay soil (Table 2 ), but regression analysis result showed that there was no significant effect of $\mathrm{pH}$ and $\mathrm{EC}$ on cumulative respiration.

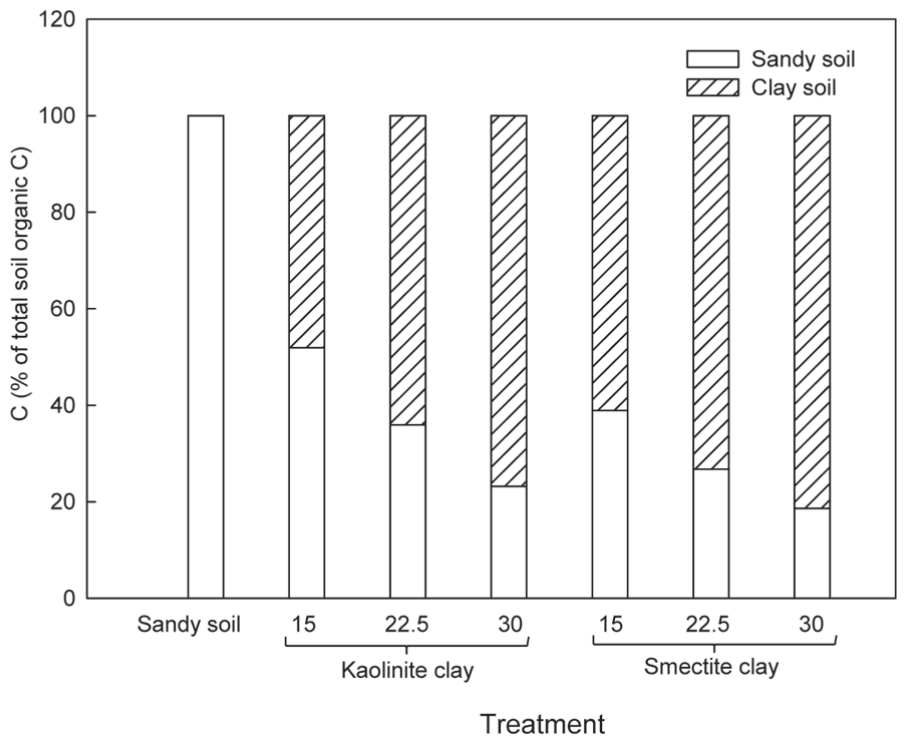

Figure 1. Proportion of total organic $C$ from sandy soil and clay soil in sandy soil alone and mixes of sandy soil with kaolinite and smectite clay soil at 15, 22.5 and $30 \%$ clay addition rate. 


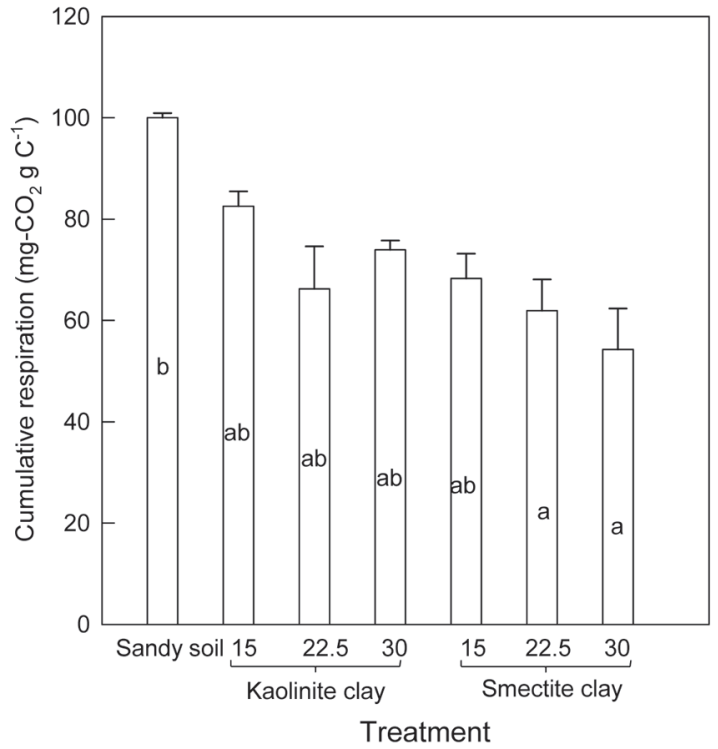

Figure 2. Cumulative respiration $\left(\mathrm{mg} \mathrm{CO}_{2} \mathrm{~g} \mathrm{C}^{-1}\right)$ of sandy soil alone and sandy soil amended with kaolinite and smectite clay at 15, 22.5 and $30 \%$ clay addition. Different letters indicate significant differences $(P \leq 0.05)(n=3)$.

Table 2. Calculated contribution to cumulative respiration (\%), $\mathrm{pH}$ and electrical conductivity in sandy soil + clay soil mixes sandy soil, kaolinite and smectite clay soil at $15,22.5$ and $30 \%$ clay addition rate.

\begin{tabular}{|c|c|c|c|c|c|c|}
\hline \multirow[t]{2}{*}{ Treatment } & \multirow{2}{*}{$\begin{array}{c}\text { Clay } \\
\text { addition } \\
\text { rate }(\%)\end{array}$} & \multicolumn{3}{|c|}{$\begin{array}{l}\% \text { contribution to cumulative } \\
\text { respiration from }\end{array}$} & \multirow[t]{2}{*}{$\mathrm{pH}$} & \multirow{2}{*}{$\begin{array}{c}\text { Electrical } \\
\text { conductivity } \\
\left(\mu \mathrm{S} \mathrm{cm}^{-1}\right)\end{array}$} \\
\hline & & Sandy & $\begin{array}{l}\text { Kaolinite } \\
\text { clay soil }\end{array}$ & $\begin{array}{l}\text { Smectite } \\
\text { clay soil }\end{array}$ & & \\
\hline Sandy soil & 15 & 53 & 47 & - & 6.3 & 25 \\
\hline \multirow[t]{2}{*}{+ kaolinite clay } & 22.5 & 37 & 63 & - & 6.3 & 32 \\
\hline & 30 & 24 & 76 & - & 6.3 & 41 \\
\hline Sandy soil & 15 & 75 & - & 25 & 9.7 & 411 \\
\hline \multirow[t]{2}{*}{+ smectite clay } & 22.5 & 63 & - & 37 & 9.7 & 486 \\
\hline & 30 & 52 & - & 48 & 9.6 & 567 \\
\hline
\end{tabular}




\section{Discussion}

This study showed that the effect of clay soil addition to sandy soils depends on clay type and to a lesser extent on clay addition rate. Addition of smectite clay soil decreased cumulative respiration per $\mathrm{g}$ organic $\mathrm{C}$ in the sand-clay mixes compared to sandy soil alone at 22.5 and $30 \%$ clay addition rates whereas addition of kaolinite clay soil had no effect at any clay addition rate (Figure 2). The low cumulative respiration of the mixes with smectite clay soil can be explained by its high surface area and CEC and thus binding capacity for organic $\mathrm{C}$ (OC) which reduces accessibility of OC to microbes (Baldock, 2007). This confirms our first hypothesis (compared to sandy soil alone, respiration will be more strongly reduced by addition of a smectiterich clay soil than by a kaolinite-rich soil). The reduction of cumulative respiration per $\mathrm{g}$ organic $\mathrm{C}$ by addition of smectite clay soil can be explained by the low respiration rate of the smectite clay soil alone (Table 1). This is also evident in the low contribution of the smectite clay soil to cumulative respiration of the mix (Table 2). Thus, although the OC content of the smectite clay soil was greater than of the kaolinite clay soil, it was not accessible to soil microbes. Fe oxides can bind organic matter and thereby reduce accessibility to microbes (Kaiser, et al. 1996), but although the concentration of $\mathrm{Fe}$ oxides was greater in the kaolinite than the smectite clay soil, accessibility was lower in the latter. The reduction in cumulative respiration by smectite clay soil occurred only at the two higher clay addition rates suggesting that in sandy- clay soil mixes, smectite addition only reduces respiration when the contribution of smectiteOC to total OC in the mix is $\geq 64 \%$.

Cumulative respiration decreased with increasing clay addition rate only in the mixes with smectite clay soil. Thus, our second hypothesis (the reduction of respiration by clay will increase with clay addition rate) is true only for sandy soil with smectite clay soil, not for those with kaolinite clay soil. The finding that addition of kaolinite clay soil had no effect on cumulative respiration compared to sandy soil alone at all clay rates can be explained by the similar respiration per g OC of sandy soil and kaolinite clay soil (Table 1). Kaolinite clay soil contributed more to total respiration of the mix than sandy soil (Table 2) although the amount of clay soil in the mix was less than that of the sandy soil at the two lower clay addition rates. However, kaolinite clay soil had a higher total OC content than sandy soil and therefore contributed similar or more to the total OC than sandy soil (Figure 1).

We conclude that the reduction of cumulative respiration at higher rates of clay addition by smectite clay soil can be explained its greater surface area and CEC compared to the kaolinite clay soil which leads to a greater protection of OC by the smectite clay soil, This suggests that addition of smectite-rich clay subsoils will result in greater organic $\mathrm{C}$ stabilization than kaoliniterich clay soils. However, both clay soils may increase yield and thus $\mathrm{C}$ input through increased nutrient and water retention. Further research is required to investigate the effect of clay type and rate on OC input and retention of added OC. 


\section{Acknowledgement}

The authors would like to acknowledge Amanda Schapel for supplying the sandy and the kaolinite clay soil and Serhiy Marchuk for the smectite clay soil.

\section{References}

Amato M., Ladd, J.N. 1992. Decomposition of ${ }^{14} \mathrm{C}$-labelled glucose and legume material in soils: Properties influencing the accumulation of organic residue $\mathrm{C}$ and microbial biomass C. Soil Biol. Biochem. 24, 455-464.

Amezketa, E. 1999. Soil aggregate stability: A review. J. Sustain. Agr. 14, 83-151.

Baldock, J.A. 2007. Composition and cycling of organic carbon in soil. In nutrient cycling in terrestrial ecosystems. Eds. P. Marschner and Rengel, Z. Springer, Berlin.

Brindley, G.W. 1980. Quantitative X-ray mineral analysis of clays. Mineralogical Society, London.

Hall, D.J.M., Jones, H.R., Crabtree, W.L., Daniels, T.L. 2010. Claying and deep ripping can increase crop yields and profits on water repellent sands with marginal fertility in southern Western Australia. Soil Res. 48, 178-187.
Kaiser, K., Guggenberger, G., Zech, W. 1996. Sorption of DOM and DOM fractions to forest soils. Geoderma. 74, 281-303.

Newman, A.C.D. 1983. The specific surface of soils determined by water sorption. J. Soil Sci. 34, 23-32.

Rayment, G.E., Lyons, D.J. 2011. Soil Chemical Methods - Australasia. CSIRO Publishing, Victoria, Australia.

Roychand, P., Marschner, P. 2013. Respiration in a sand amended with clay - Effect of residue type and rate. Eur. J. Soil. Biol. 58, 19-23.

Setia, R., Marschner, P., Baldock, J., Chittleborough, D., Smith, P., Smith, J. 2011. Salinity effects on carbon mineralization in soils of varying texture. Soil Biol. Biochem. 43, 1908-1916.

Shi, A., Marschner, P. 2012. Addition of a clay subsoil to a sandy top soil alters $\mathrm{CO}_{2}$ release and the interactions in residue mixtures. Sci. Total Environ. 465, 248-254. 
